\title{
AGRESSÃO FÍSICA E GÊNERO NA CIDADE DO RIO DE JANEIRO
}

\author{
Alba Zaluar
}

Em 2005-2006, o Nupevi - Núcleo de Pesquisa das Violências realizou um inquérito domiciliar de vitimização cujo universo foi a população de 15 anos e mais na cidade do Rio de Janeiro. Foram aplicados 3.435 questionários aleatoriamente em 200 setores censitários, 20 domicílios em cada setor e uma pessoa de 15 anos ou mais em cada domicílio, ou seja, a amostra foi aleatória em três estágios. Em 2007, repetiu-se o mesmo instrumento em favelas da cidade, contando 660 pessoas entrevistadas. Nas duas, procurou-se manter uma fração de amostragem de aproximadamente 1/1500.

A pesquisa de vitimização permite conhecer a freqüência, a natureza e as circunstâncias de crimes e agressões que vitimam pessoas, pois nem sempre são registrados na polícia por diferentes razões. Portanto, esse tipo de estudo é fundamental

Artigo recebido em abril/ 2009

Aprovado em junbo/2009 para aferir o problema da cifra oculta da criminalidade, ou seja, a subestimação do risco. Ao mesmo tempo, permite analisar os perfis das vítimas e de seus agressores, o relacionamento entre eles e as circunstâncias nas quais os crimes ocorreram. Por fim, recolhem-se dados sistemáticos sobre a experiência das vítimas com o sistema policial e de atendimento hospitalar de emergência, assim como as diversas medidas tomadas pelas pessoas para se precaver dos delitos ou reagir a eles. É também instrumento fundamental para se entender por que as pessoas procuram ou não a polícia em face de cada um dos crimes sofridos por elas. A partir dos seus bancos de dados é possível descobrir padrões passíveis de novas explicações e encontrar soluções aplicáveis em políticas públicas.

Neste texto, apresento apenas os dados sobre as agressões físicas sofridas por pessoas de 15 anos e mais nos doze meses anteriores ao momento da 
pesquisa, assim como aquelas sofridas na vida toda até o momento da pesquisa. Isto porque a agressão física tem um padrão muito peculiar, entre os crimes averiguados, visto que obedece a motivações e circunstâncias específicas, muito mais relacionadas com as interações e emoções entre as pessoas envolvidas do que com a oportunidade, muito mais relacionadas com o poder e o reconhecimento simbólico para o agressor do que com os ganhos materiais obtidos no furto e no roubo. Por isso, oferece argumentos importantes para debater a teoria da escolha racional na aferição e na compreensão da criminalidade. Serve também para discutir a necessidade de se usar tão-somente a teoria da família patriarcal como explicação de tais sentimentos e relações que propiciariam principalmente agressões contra as mulheres.

No entanto, é preciso lembrar que o registro, mesmo que realizado por questionários aplicados nos locais de residência das vítimas, com todos os cuidados sobre a confidencialidade e a independência de quem o faz, livre de pressões de outros moradores do mesmo local, depende da percepção que a vítima tem do que seja agressão. Simião aponta para essa dimensão tão importante quando da interpretação seja de registros policiais, seja de registros obtidos em pesquisa de campo por um instrumento:

O aumento do número de denúncias deve ser analisado, assim, dentro do processo de construção de uma narrativa de gênero que altera a forma como a corporalidade é vivida em grande parte do país. Gestos e atitudes em relação ao corpo, usualmente tidos como naturais, tornam-se atitudes de violência [...] (Simião, 2006).

A primeira pesquisa mostrou que a agressão física tem percentual baixo na cidade do Rio de Janeiro, provavelmente mais subestimado pelas vítimas do que o roubo e o furto, devido às dificuldades em falar do que teria que ser reconhecido como agressão. Nos últimos doze meses, $2 \%$ de moradores da cidade com 15 anos e mais disseram que foram agredidos nos últimos doze meses, e $8,9 \%$ na vida toda. As mulheres foram mais agredidas do que os homens nos últimos doze meses - 2,6\% para elas e $1,2 \%$ para eles -, assim como na vida toda $-9,4 \%$ para elas e $8 \%$ para eles. Na pesquisa feita apenas nas favelas em 2007, as proporções são três vezes maior nos últimos doze meses $(7,3 \%)$ e quase o dobro da cidade quando se considera as agressões na vida toda $(13,8 \%)$. Isto demonstra que essa manifestação da violência, como no caso dos assassinatos, é mais comum nas favelas cariocas do que na cidade.

Outro ponto que demonstra a especificidade da agressão é que, ao contrário do que acontece com o furto e o roubo, as mulheres são pouco mais agredidas do que os homens, o que revela que as mulheres já adquiriram sensibilidade e coragem para assinalá-la. Nas favelas, porém, os percentuais, além de mais altos do que na cidade, são estatisticamente similares para homens e mulheres $(13,3 \%$ e $12,8 \%$, respectivamente), indicando um nível de agressividade interpessoal mais alto nas favelas, sem importar o gênero. ${ }^{1}$

Mas há diferenças nas proporções de agressões entre homens e mulheres, brancos, pardos e pretos, categorias de renda e de escolaridade, tanto na cidade como nas favelas. A agressão física inverte outras tendências encontradas nos furtos e nos roubos: o pobre mais do que o rico, o de menor escolaridade mais do que o com primeiro ou segundo graus completos, o preto e pardo mais do que o branco, sendo que a diferença de risco por raça/cor, submetida ao teste qui-quadrado, é altamente significante na cidade $(p=0,00003)$, mas não na favela $(p=0,01036)$, do mesmo modo que a renda é significante na cidade $(p=0,00040)$, mas não na favela $(p=0,13027)$.

$\mathrm{Na}$ cidade do Rio de Janeiro, o local onde ocorreu a última agressão tem, na agressão física, padrão diferente do roubo e do furto, mas é principalmente diverso entre homens e mulheres. Entre os homens, os locais predominantes são as ruas do bairro onde moram, atingindo $37,4 \%$ dos agredidos; as ruas fora do bairro, que somaram $22,9 \%$; outros locais de encontro entre homens (bares, casas noturnas, bailes, estádios) que importaram 13,4\%. Ou seja, 73,7\% das agressões ocorreram em locais públicos. Entre as mulheres, o local de maior incidência de agressões é a residência da entrevistada (50,7\%) e as residências de parentes e vizinhos $(7,1 \%)$, isto é, $57,8 \%$ em ambientes domésticos e privados.

Nas favelas, as estimativas são ligeiramente diferentes, mas mantém-se o padrão público para os homens e o padrão privado para as mulheres. Os 
homens foram agredidos nas ruas e nas praças do bairro $(52 \%)$, externamente ao bairro $(17 \%)$, totalizando $74 \%$ em locais públicos, ao passo que apenas $24 \%$ deles o foram em casa, duas vezes e meia mais do que na cidade. Isto sugere que há mais agressão doméstica e na vizinhança para os homens favelados. Esta particularidade das favelas também afeta as mulheres, que são mais atacadas em casa ou na residência de vizinhos, somando $66,9 \%$ agredidas em cenários domésticos, proporção bem maior do que as agredidas nas ruas do seu bairro $(23,5 \%)$ e fora do bairro $(9 \%)$.

\section{Gráfico 1}

Estimativas dos locais onde os homens moradores de favelas com 15 anos ou mais foram agredidos pela última vez

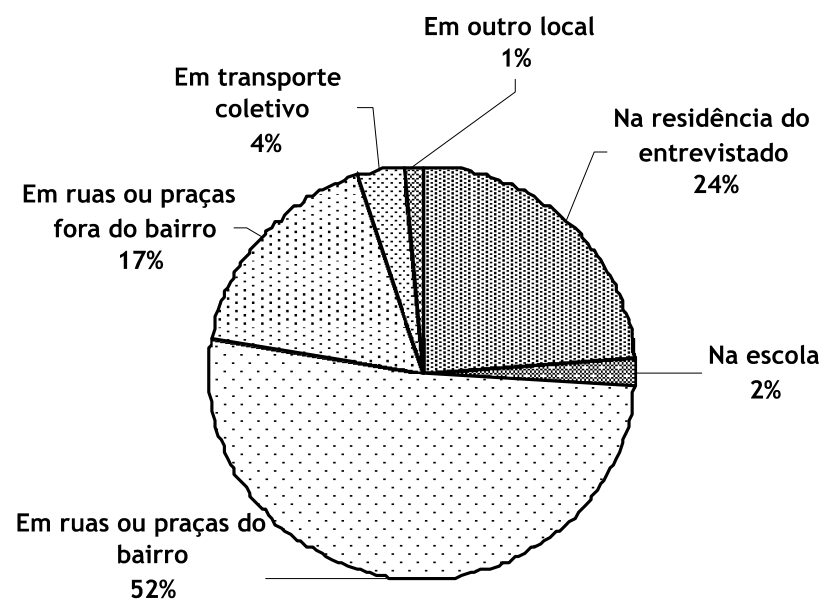

Fonte: Pesquisa Domiciliar de Vitimização, Favelas do Rio de Janeiro, 2007, Nupevi/Uerj.

\section{Gráfico 2}

Estimativas dos locais onde as mulheres moradoras de favelas com 15 anos ou mais foram agredidas pela última vez

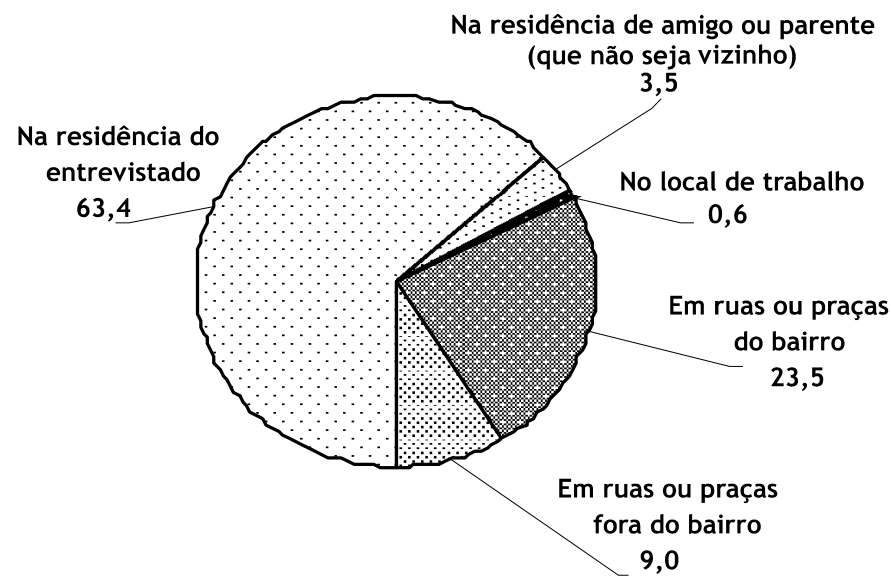

Fonte: Pesquisa Domiciliar de Vitimização, Favelas do Rio de Janeiro, 2007, Nupevi/Uerj. 
Os horários e os dias de semana da agressão também têm padrão diferente do roubo e do furto, e são igualmente diversos entre os homens e as mulheres. Entre os homens, o pico é no fim de semana à noite. Trata-se, portanto, mais do que o furto e o roubo, de uma atividade noturna e vinculada a atividades de lazer no fim de semana, quando os homens se encontram e dividem espaços e atividades (Cecchetto, 2004; Monteiro, 2003).
Entre as mulheres, o pico é no dia de semana à noite e à tarde, voltando a subir um pouco no fim de semana à noite. Essas curvas diversas de horários condizem com o padrão público da agressão masculina e o padrão doméstico da agressão contra as mulheres, visto que esta coincide com os horários em que os homens voltam para casa, ou vindos do trabalho ou das atividades de lazer no fim de semana.

Gráfico 3

Estimativas de percentuais dos dias e horários em que os homens de 15 anos ou mais foram agredidos fisicamente pela última vez

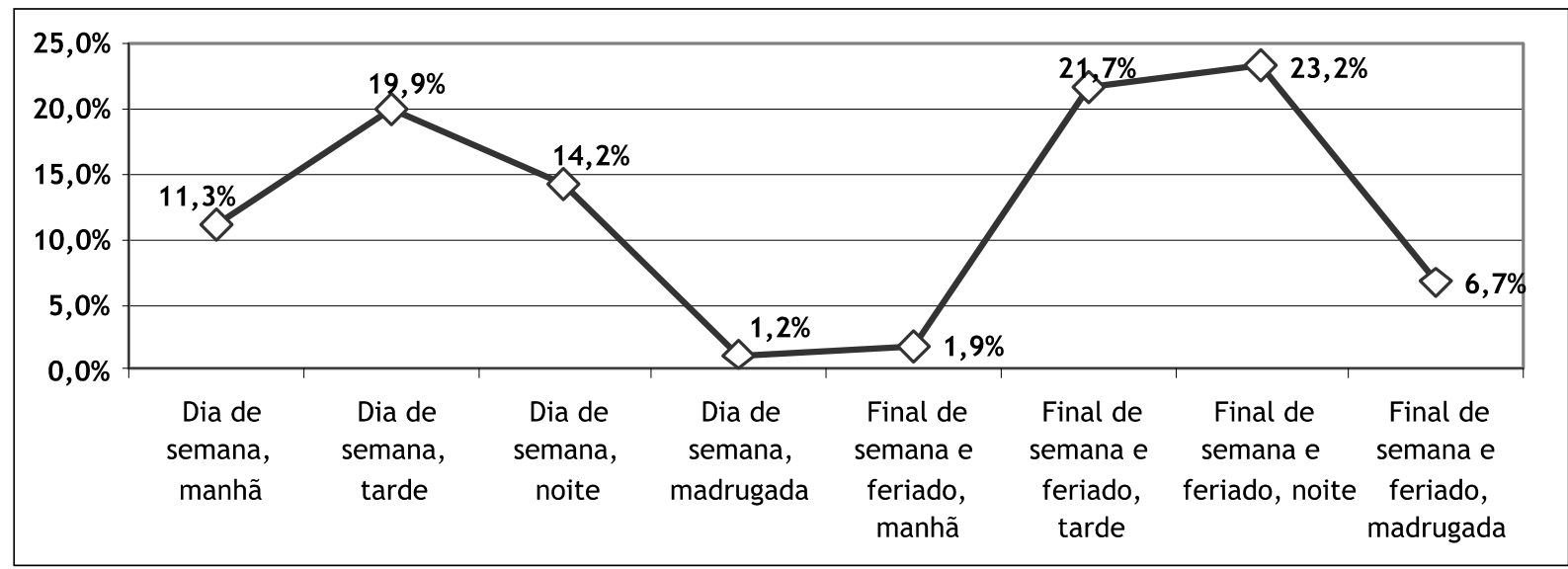

Fonte: Pesquisa Domiciliar de Vitimização, Cidade do Rio de Janeiro, 2005-2006, Nupevi/Uerj.

\section{Gráfico 4}

Estimativas de percentuais dos dias e horários em que as mulheres de 15 anos ou mais foram agredidas fisicamente pela última vez

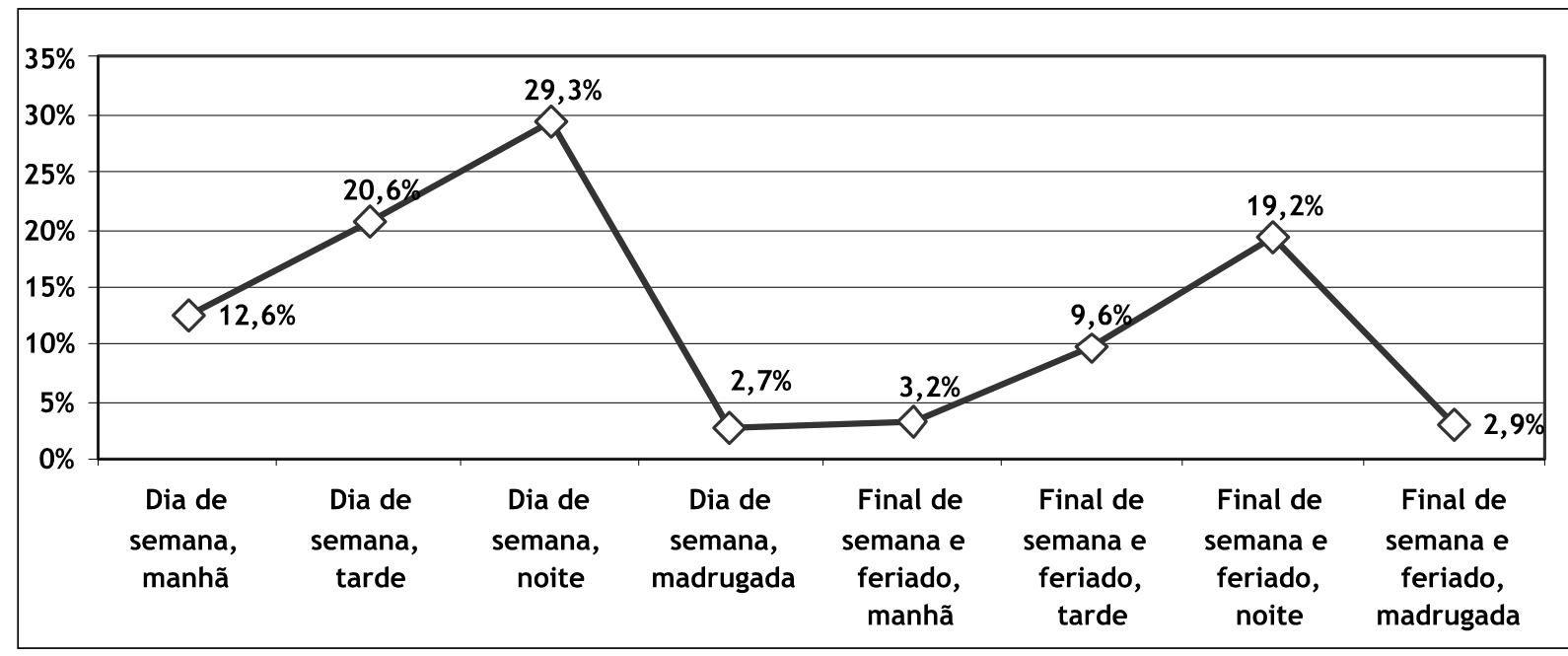

Fonte: Pesquisa Domiciliar de Vitimização, Cidade do Rio de Janeiro, 2005-2006, Nupevi/Uerj. 
Nas favelas, também há diferenças na agressão visto que, excluída a proporção quase duas vezes maior no dia de semana à tarde e uma pequena proporção na madrugada de fins de semana, as curvas apresentadas por homens e mulheres são mais parecidas entre si do que na cidade. Isto indica que as agressões contra elas também ocorrem mais nas noites da semana, dois picos coincidentes com as agressões dos homens, provavelmente relacionados com o fato de que o lazer acontece na própria favela e envolvem mais vizinhos. Não há registro de agressões nas madrugadas de feriados e fins de semana, o que também sugere um padrão de lazer mais territorializado, próprio de locais relativamente mais isolados do seu contorno social.

Gráfico 5

Estimativas dos dias e horários em que os homens moradores de favelas com 15 anos ou mais foram agredidos pela última vez

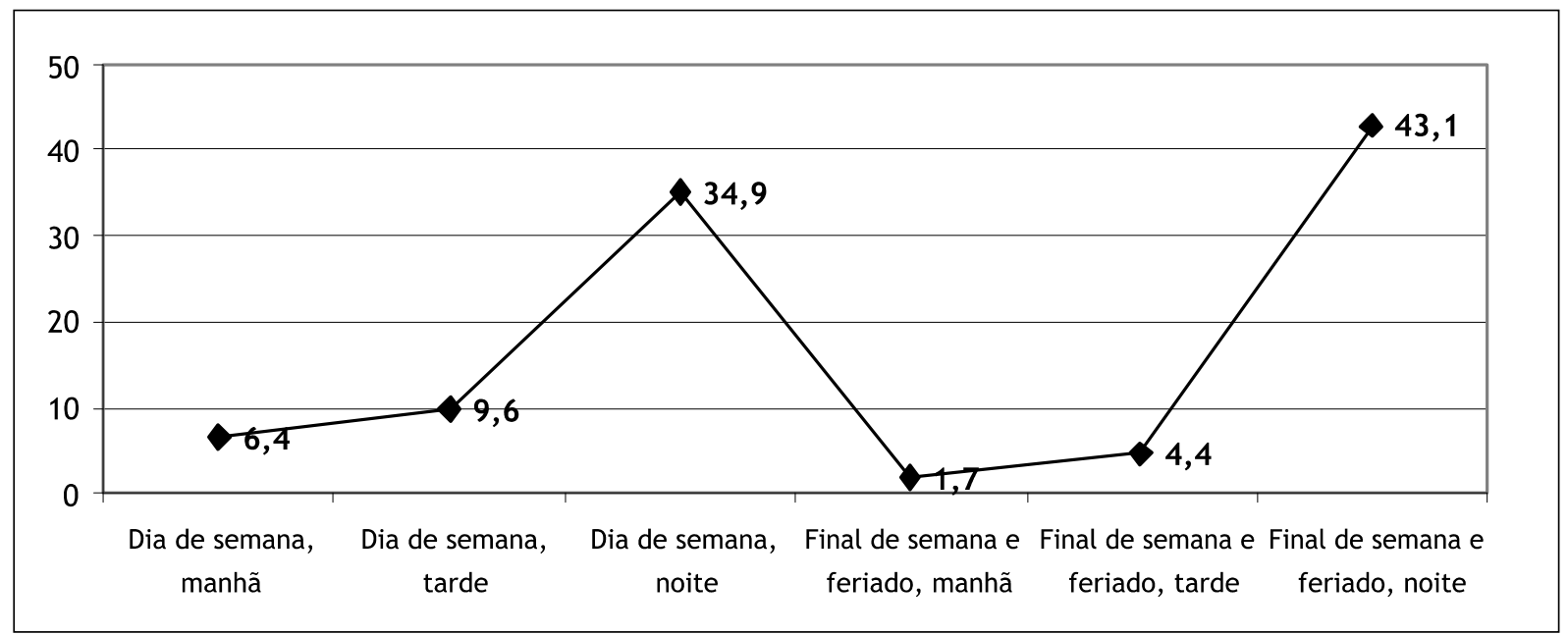

Fonte: Pesquisa Domiciliar de Vitimização, Favelas do Rio de Janeiro, 2007, Nupevi/Uerj.

Gráfico 5

Estimativa de percentuais de dias e horários em que as mulheres moradoras de favelas com 15 anos ou mais foram agredidas pela última vez

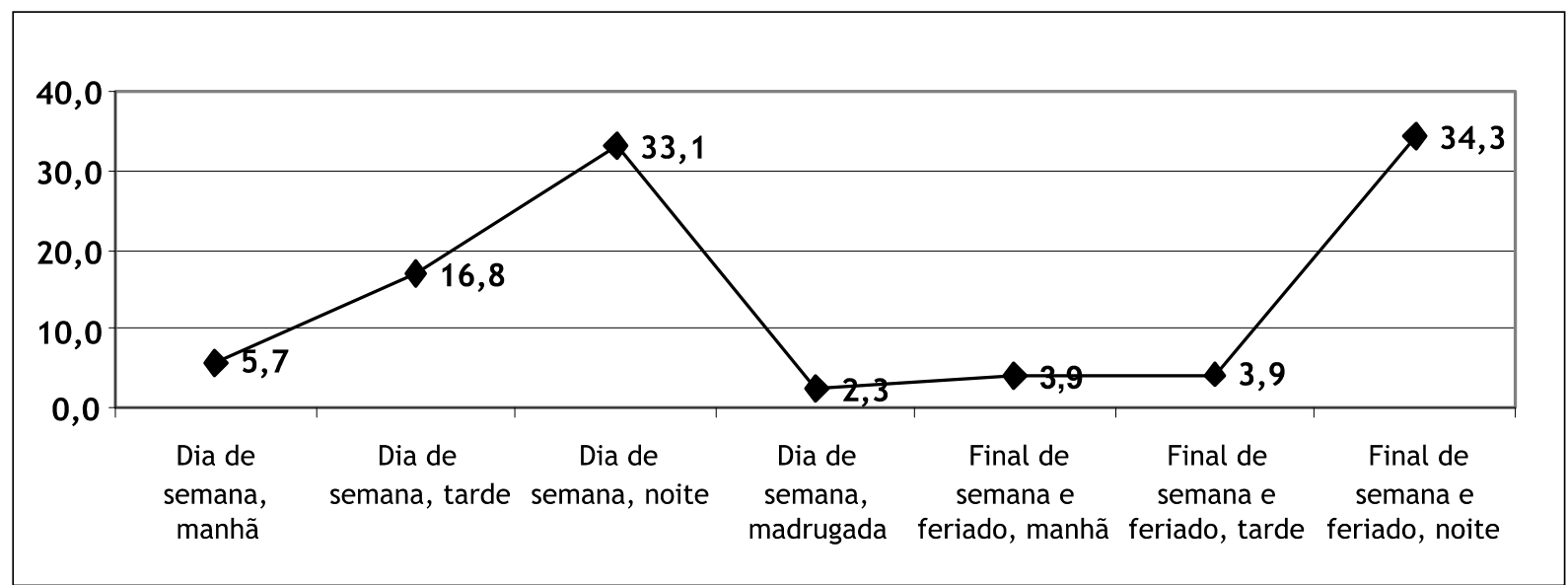

Fonte: Pesquisa Domiciliar de Vitimização, Favelas do Rio de Janeiro, 2007, Nupevi/Uerj. 
Quando se considera cor ou raça, na cidade, os pretos e os pardos foram mais agredidos do que os brancos nos últimos doze meses, com índices de $3 \%, 2,8 \%$ e $1,1 \%$ respectivamente, e na vida toda com índices de 13,9\%,10\% e 6,4\%; os de ensino fundamental mais do que os de ensino universitário nos últimos doze meses com $2,2 \%$ para os primeiros e $1,4 \%$ para os segundos, invertendo a correlação encontrada no furto e no roubo. Porém, na vida toda, as taxas relativas à escolaridade são quase que iguais: 9,2\% e 9,5\%, ou seja, a escolaridade passa a ter menos peso do que a cor/raça, a renda familiar e a idade no cálculo do risco relativo de cada categoria de pessoa ser agredida.

Quanto à idade, as mulheres na idade reprodutiva (de 20 a 40 anos) são as mais agredidas na vida toda na cidade. Os homens nessa condição estão entre 15 e 30 anos, ou seja, mais jovens. Nas favelas, além de atingir proporções bem mais altas do que na cidade, a agressão física é igualmente grave para as mulheres e os homens. No entanto, é mais freqüente entre os mais jovens $(15,1 \%$ na faixa dos 15 19 anos; $14,8 \%$ entre os $20-39$ anos; $11 \%$ entre os 40-59 anos; $5,2 \%$ com 60 anos ou mais), inclusive para as mulheres. As mulheres são mais agredidas a partir de 15 anos, já que nas favelas se casam mais cedo; a queda é lenta até aos 40, depois cai abruptamente. Os homens têm o pico aos 20-39 anos e continua caindo lentamente após os 40 anos. ${ }^{2}$

Uma das teorias mais acionadas para discutir o risco de vitimização é a da desorganização social, mais comumente operacionalizada com a variável "famílias chefiadas por mulheres" ou "incompletas", sem considerar as mudanças recentes nos padrões familiares, hoje mais diversos. Porém, os resultados da pesquisa sugerem que os modelos de família devem ser mais complexos e incluir uma gama de situações quanto ao estado civil, além de outras variáveis relacionadas com vizinhança ou bairro da cidade, não considerados aqui.

$\mathrm{Na}$ vida toda, a soma de homens e mulheres vítimas de agressão por estado civil apresenta percentuais significativos: $18,4 \%$ dos separados não oficialmente; $16,1 \%$ dos amigados; $9,8 \%$ dos solteiros; $10,9 \%$ dos desquitados, divorciados ou separados judicialmente. Os casados apresentam uma proporção $(5,3 \%)$ três vezes menor do que a dos separados e a dos amigados, assim como duas vezes menor do que a dos solteiros e a dos desquitados.

Mas há distinção entre homens e mulheres usualmente considerados "casados", porém com variações na forma da união, apesar de pertencentes a famílias completas, chefiadas por homens. Pois, nos últimos doze meses, os homens "amigados" ou em união consensual têm 4\% de agredidos, enquanto as mulheres "amigadas" atacadas chegam a 7,4\%, quase o dobro; os solteiros atingem $1,8 \%$, enquanto as solteiras, $2,8 \%$; as separadas têm $4,1 \%$ de agredidas, mas os separados, nenhum. O teste de qui quadrado nas duas pesquisas revelou que a diferença de risco por estado civil é altamente significante para uma margem de erro de $1 \%(\mathrm{p}=0,0000 \mathrm{na}$ cidade, $\mathrm{p}=0,0002$ na favela).

Esse registro é importante, visto que exige uma avaliação mais precisa do impacto da união juridicamente sacramentada ou da união consensual nos riscos que as mulheres sofrem de serem agredidas, fatos não discutidos na literatura feminista como se não houvesse diferenças. $\mathrm{O}$ argumento de que as separadas registrariam mais agressões porque teriam se separado justamente por terem sido agredidas, embora possa ser válido para a vida toda, perde sua validade no registro de agressões nos últimos doze meses.

Isto sugere que o casamento, assim como a separação ritualizada judicialmente, diminui o risco de ser agredido, ou seja, os rituais jurídicos e religiosos envolvidos no casamento e na separação podem vir a significar uma probabilidade menor de ser agredido fisicamente. Várias interpretações podem ser dadas a este dado: 1) as pessoas que se juntam e se separam sem tais rituais sofrem menos controle de suas respectivas famílias e redes de relações, ou seja, não é tanto a formalização jurídica, mas a rede de solidariedade que envolve os cônjuges que afetaria o risco de ser ou não agredido; 2) o próprio ritual judicial diminui o risco de agressão na medida em que interpõe um terceiro à relação conjugal, no caso o Judiciário; 3) o estilo de vida dos que se casam e se separam judicialmente é mais conservador ou de maior compromisso mútuo e de laços mais permanentes do que os demais, o que se manifestaria também no seu estilo de vida, distinto dos "amigados" e separados não oficialmente.

O dado que melhor revela a diferenciação dos padrões de agressão sobre o gênero, juntamente com 
o local da agressão, é a relação entre agredido e agressor, não medida por encontros fortuitos em locais e sim pela natureza dessa relação. Pelos resultados, as mulheres majoritariamente conhecem seus agressores próximos e íntimos, o que comprova o caráter familiar ou privado das agressões sofridas. Os homens, ao contrário, majoritariamente não conhecem seus agressores na cidade, embora isso se modifique nas favelas, onde a sociabilidade entre vizinhos é mais intensa.

Dos homens agredidos, $42,8 \%$ o são por amigos, vizinhos ou colegas; $40,6 \%$, por desconhecidos. Destes, $92,2 \%$ são agredidos por outros homens. Das mulheres agredidas, $67 \%$ o são por parentes e afins; $15,9 \%$, por desconhecidos. Das agredidas por parentes e afins, $98,2 \%$ são agredidas por homens, enquanto, no cômputo geral, $77,2 \%$ são agredidas por homens. Simplificando, poderse-ia dizer que os homens são mais propícios a brigar entre si, conhecendo-se ou não, e as mulheres a apanhar de homens mais próximos e, portanto, conhecidos. No último caso, a lógica é a da obediência pelo medo, como na submissão ao domínio masculino; no primeiro, a lógica da resposta ao desafio como recusa a qualquer submissão (Bourdieu, 1972) e a conseqüente afirmação do etos da masculinidade dominadora, insubmissa, desafiadora.

\section{Gráfico 7}

Percentuais dos últimos agressores dos homens com 15 anos ou mais

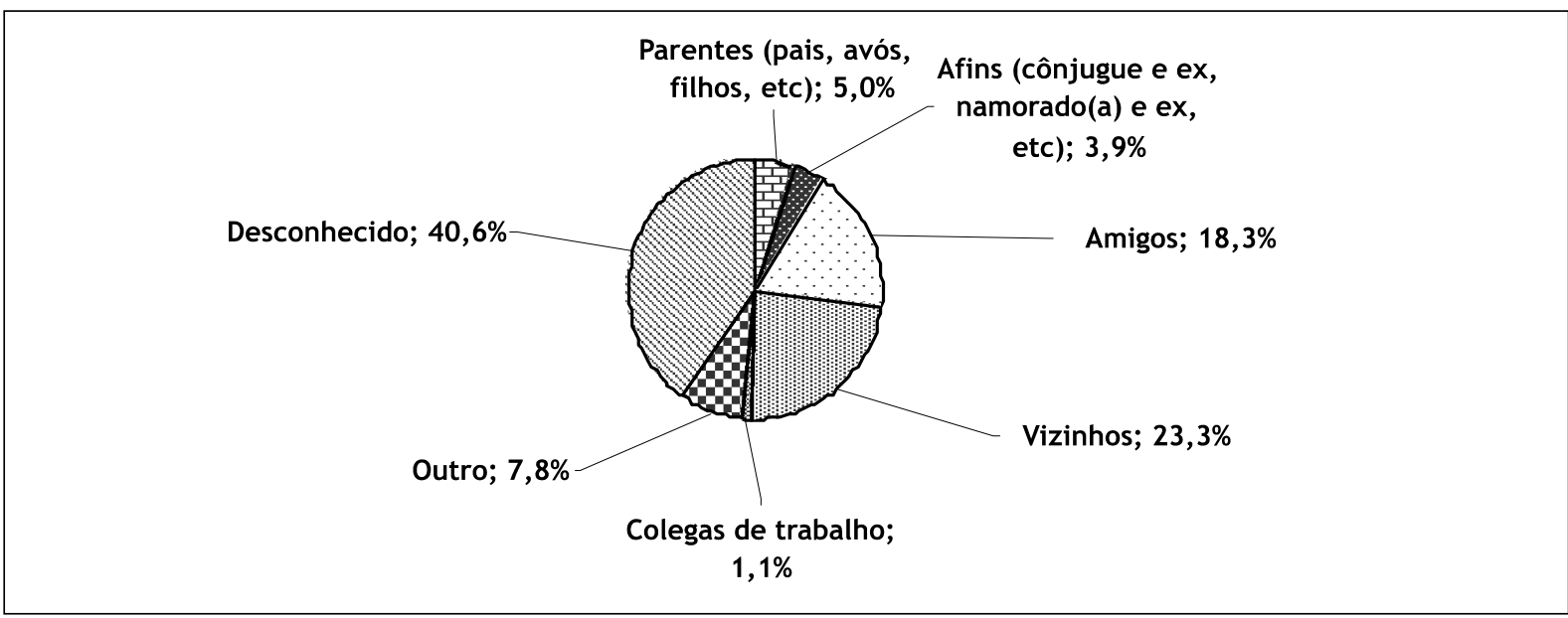

Fonte: Pesquisa Domiciliar de Vitimização, Cidade do Rio de Janeiro, 2005-2006, Nupevi/Uerj.

\section{Gráfico 8}

Percentuais dos últimos agressores das mulheres com 15 anos ou mais

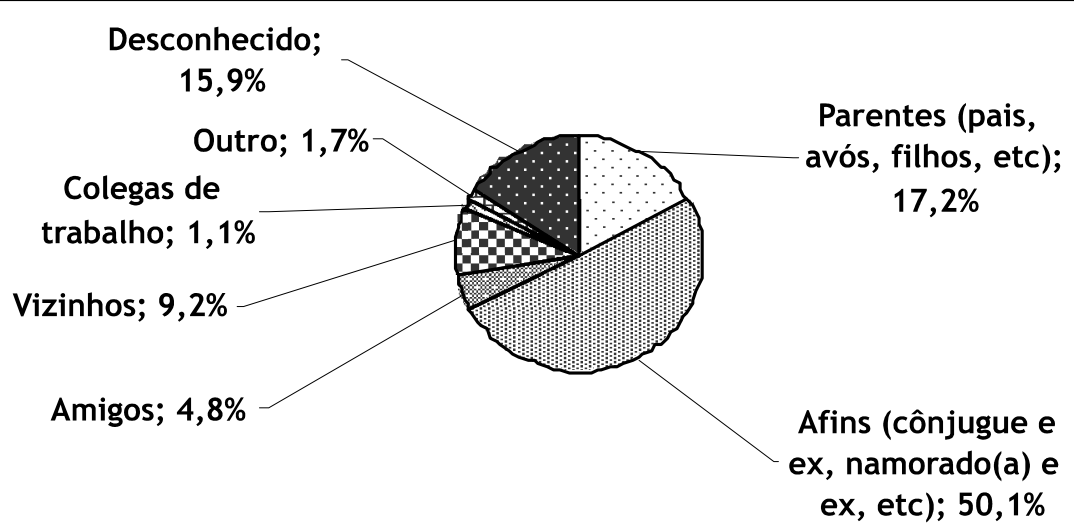

Fonte: Pesquisa Domiciliar de Vitimização, Cidade do Rio de Janeiro, 2005-2006, Nupevi/Uerj. 
Nas favelas, entre os homens agredidos a proporção mais alta de seus agressores é a de vizinhos (33\%, mais de três vezes maior do que na cidade), outros (principalmente policiais, 18,6\%, mais do que o dobro da cidade), desconhecidos (19,9\%), somando $77,3 \%$ por desconhecidos, amigos e vizinhos, dos quais $92,5 \%$ por homens, o que aponta consistentemente para práticas de lazer na própria favela. Parentes e afins somam $21,9 \%$. Entre as agredidas, repetese o mesmo padrão da violência doméstica encontrado na cidade com uma proporção maior, pois os parentes e afins (principalmente companheiros e ex-companheiros) contam com $59 \%$, e parentes consangüíneos com $17 \%$, totalizando $76 \%$ de agressores vinculados à esfera doméstica, bem maior do que na cidade. A agressão por vizinhos e outros (principalmente policiais) é também maior entre as faveladas, sete vezes maior do que na cidade. Nas favelas, $88 \%$ das mulheres foram agredidas por homens, percentual maior do que na cidade. Isto indica que os padrões da violência masculina e privada contra as mulheres é mais recorrente nas favelas do que na cidade.

Gráfico 9

Percentual do tipo de relação dos agressores com suas vítimas masculinas moradores de favelas

Colegas de trabalho

Fonte: Pesquisa Domiciliar de Vitimização, Favelas do Rio de Janeiro, 2007, Nupevi/Uerj.

Gráfico 10

Percentual do tipo de relação dos agressores com suas vítimas femininas moradoras de favelas

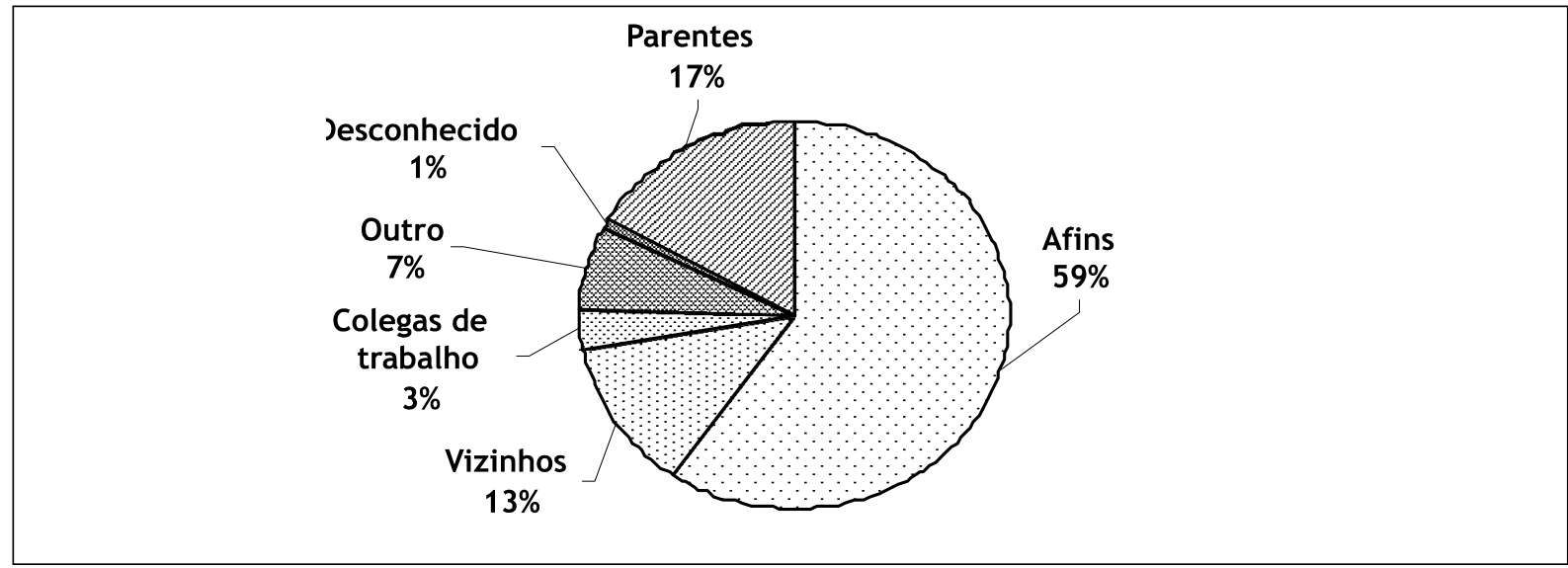

Fonte: Pesquisa Domiciliar de Vitimização, Favelas do Rio de Janeiro, 2007, Nupevi/Uerj. 
Entre as mulheres, as mais agredidas são as negras e as de baixa escolaridade. Quanto ao abuso, definido por nós como o sofrido por pessoas agredidas mais de cinco vezes na vida, os homens e as mulheres brancas são muito menos abusados no nível universitário, mas há uma alta proporção - de uma a quatro agressões - entre homens brancos e pretos nessa categoria. Isto pode ocorrer devido aos padrões diferentes de lazer noturno adotados pelos universitários, mais longe de casa e da vizinhança, que os expõe mais a ataques de desconhecidos. Porém, o teste de qui quadrado revelou que a diferença de risco por raça é altamente significante na cidade $(\mathrm{p}=0,00003)$, mas na favela seria signi- ficativo caso a margem de erro fosse menor que $5 \%(\mathrm{p}=0,01036)$. Já a diferença de risco por escolaridade não é estatisticamente significante na cidade $(\mathrm{p}=0,73536) \mathrm{e}$, na favela, apenas quando a margem de erro é de $10 \%(\mathrm{p}=0,09486)$.

No cômputo geral, as mulheres são mais abusadas, ou seja, agredidas mais de cinco vezes na vida toda, do que os homens que sofrem um número menor de agressões durante a vida. $\mathrm{Mu}-$ lheres de nível fundamental são duas vezes mais agredidas do que homens. O abuso, ou seja, repetidas agressões, é várias vezes maior entre mulheres de nível fundamental e de renda familiar mais baixa.

Gráfico 11

Estimativas de percentuais das pessoas com 15 anos ou mais agredidas mais de 5 vezes na vida toda por cor, sexo e escolaridade

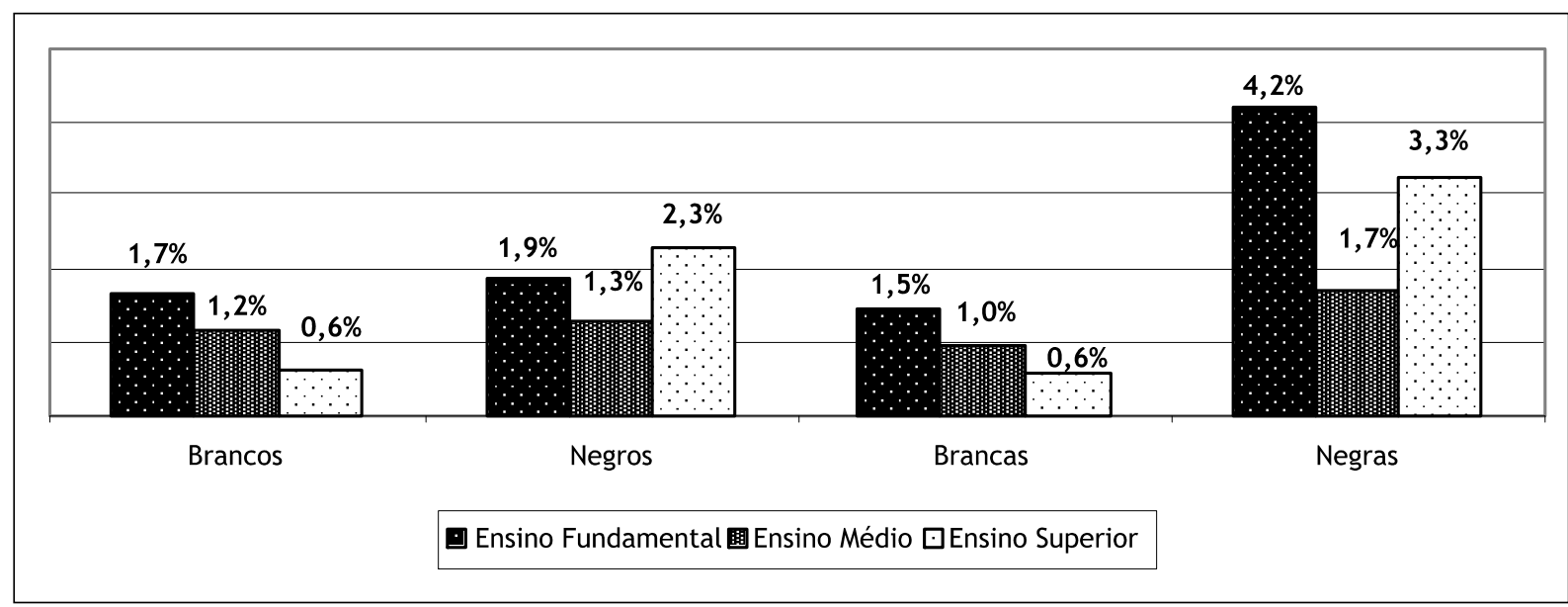

Fonte: Pesquisa Domiciliar de Vitimização, Favelas do Rio de Janeiro, 2007, Nupevi/Uerj.

Do mesmo modo, quando se compara as proporções de agressão física por Áreas de Planejamento (AP) da cidade, constata-se que são as áreas onde se concentram os mais pobres as que apresentam percentuais mais altos de pessoas agredidas. ${ }^{3}$ Porém há diferenças entre as áreas mais pobres da cidade: AP1, AP3.2, AP3.3 e AP5.3 destacam-se pelos maiores percentuais. Essas são justamente as áreas onde existem mais territórios dominados por quadrilhas de traficantes e outras formas de crime organizado, como as "milícias" recentemente organizadas para explorar, sobre os moradores, várias atividades lucrativas (Zaluar e
Conceição, 2007). Não por acaso, um percentual três vezes maior de homens agredidos perdeu vizinhos assassinados em comparação com os não agredidos $(15 \%$ para $5 \%)$. No entanto, não há grande diferença entre favelas dominadas por traficantes de drogas e as dominadas por "milícias" no tocante à agressão: nestas, o porcentual de homens agredidos $(15,8 \%)$ suplanta o das favelas dominadas por quadrilhas de traficantes $(12,6 \%)$, mas é estatisticamente igual entre as mulheres agredidas (Idem). São, portanto, áreas marcadas por uma infra-estrutura urbana mais precária ou maior percepção de desordem social, como acontece nas áreas mais pobres 
da cidade, assim como pelos crimes cometidos na frente dos moradores, o que revela a importância da presença de um terceiro nas relações: o Estado na administração da Justiça. Em outras palavras, são áreas em que há mais irregularidade, mais desordem, mais ilicitude, mais crime e mais impunidade.

\section{Gráfico 12}

Estimativas de percentual das pessoas agredidas na vida toda por sexo, em cada classe de renda familiar

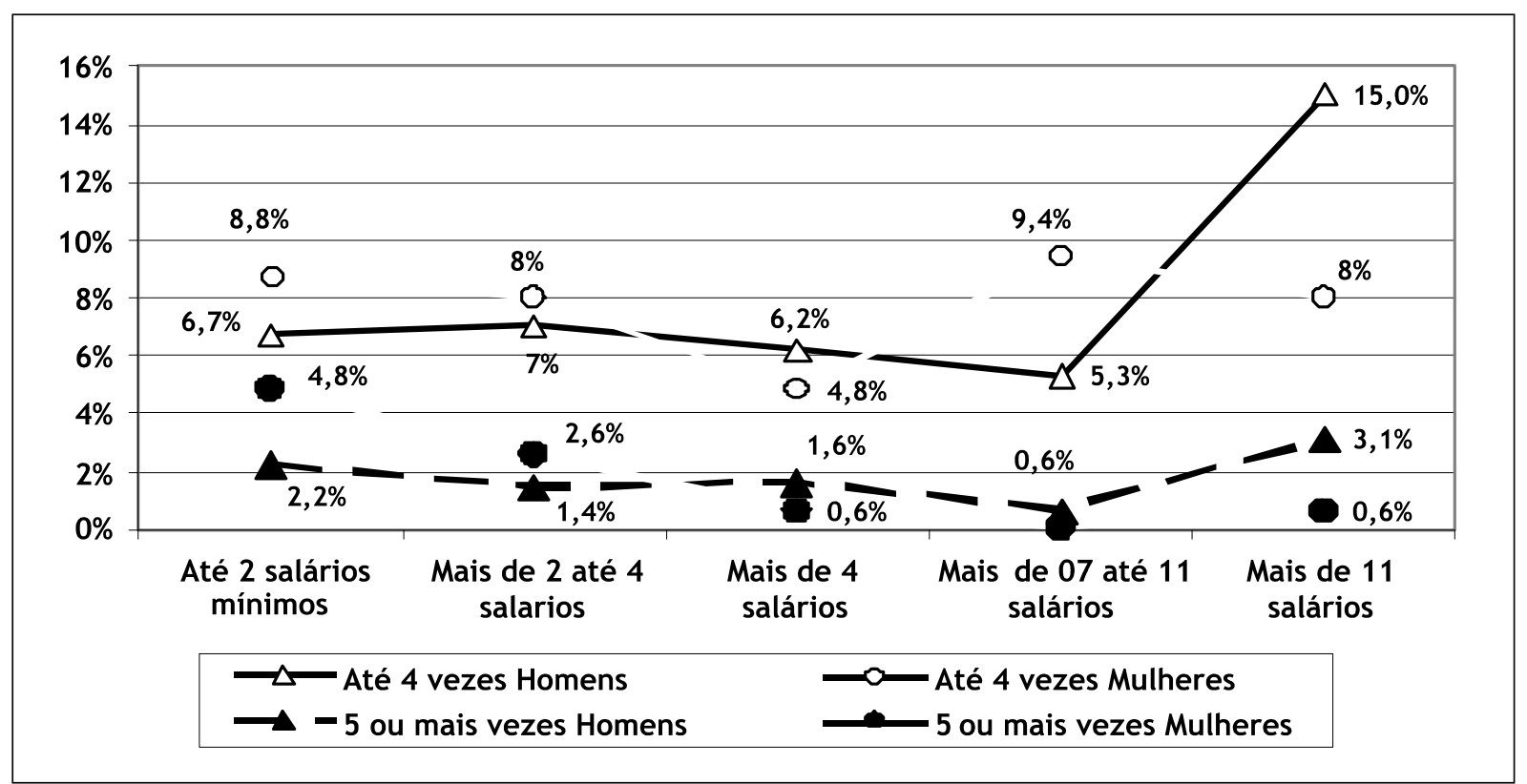

Fonte: Pesquisa Domiciliar de Vitimização, Favelas do Rio de Janeiro, 2007, Nupevi/Uerj.

\section{Gráfico 13}

Estimativas de agressão física por área de planejamento da cidade do Rio de Janeiro

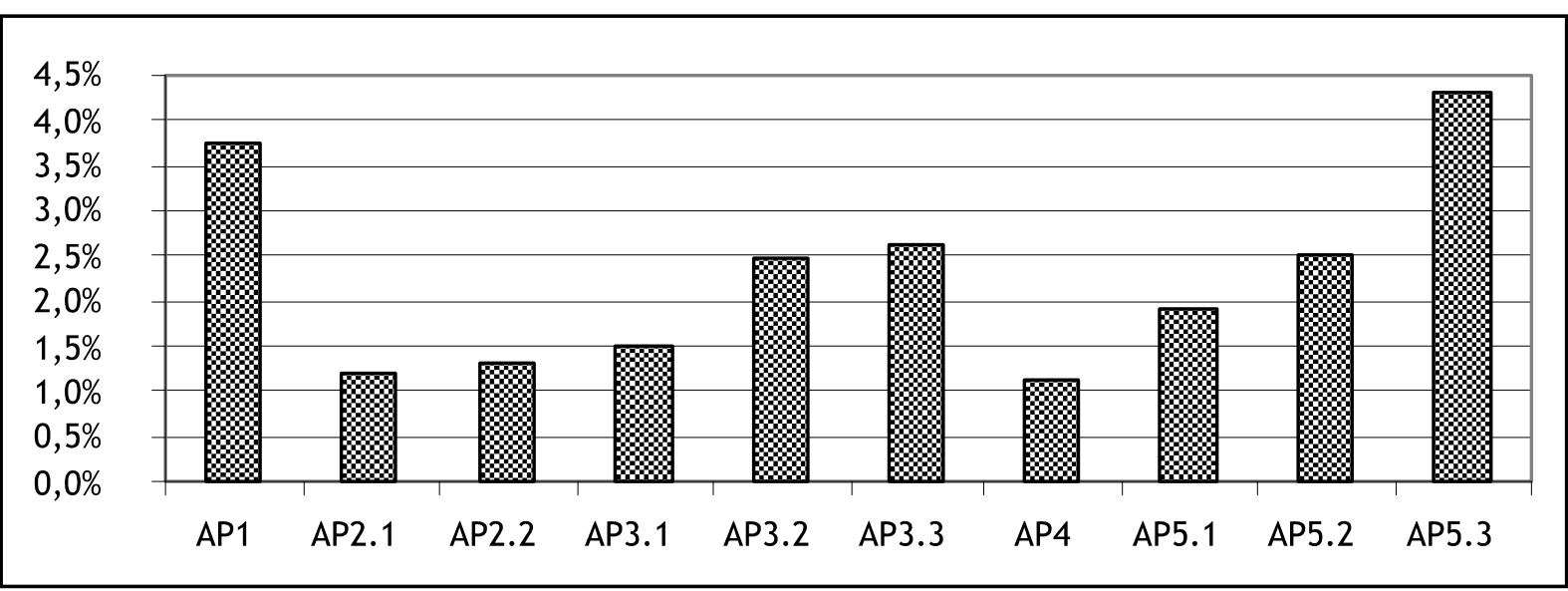

Fonte: Pesquisa Domiciliar de Vitimização, Cidade do Rio de Janeiro, 2005-2006, Nupevi/Uerj. 


\section{Gráfico 14}

Estimativas de de percentuais de crimes vistos e ouvidos por moradores de favelas em cada área de planejamento

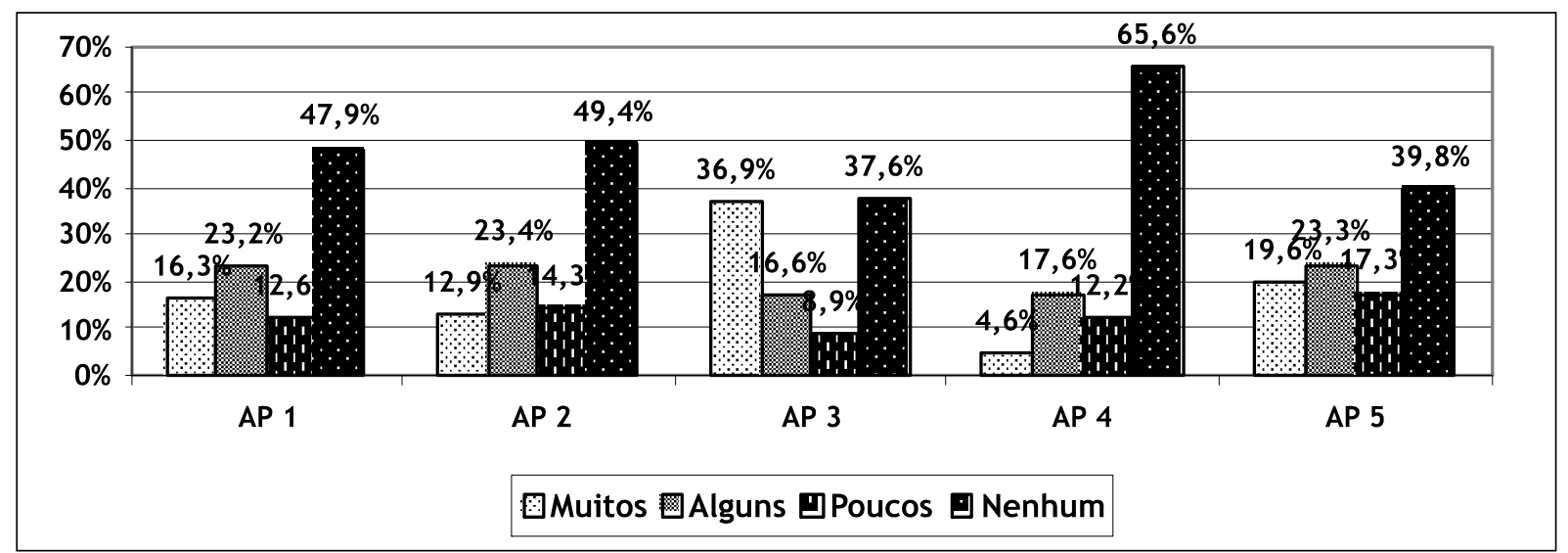

Fonte: Pesquisa Domiciliar de Vitimização, favelas do Rio de Janeiro, 2007, Nupevi/Uerj.

Gráfico 15

Estimativas de de percentuais de freqüência com que moradores de favelas dizem ouvir barulhos de tiro por área de planejamento

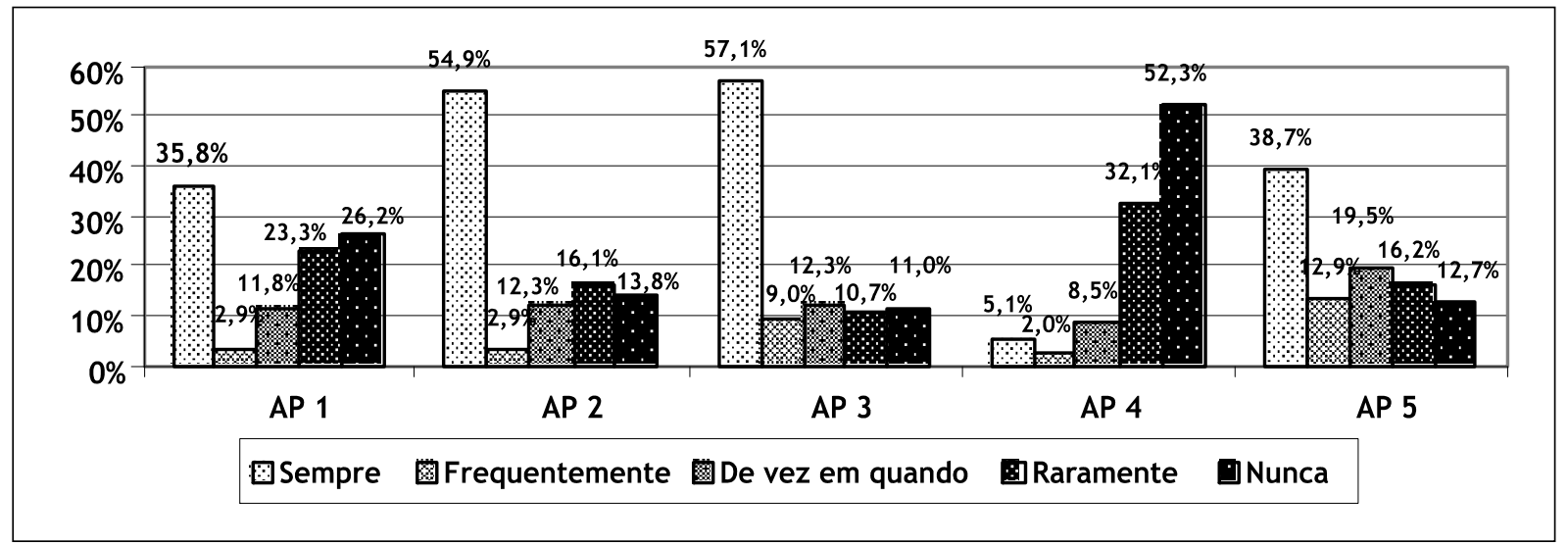

Fonte: Pesquisa Domiciliar de Vitimização, favelas do Rio de Janeiro, 2007, Nupevi/Uerj.

Os homens revidam mais a agressão (35,4\% dos agredidos para $28 \%$ das agredidas); as mulheres tendem mais a gritar para chamar atenção de outrem, não reagir ou fugir $(48,1 \%$ das agredidas para $34,8 \%$ dos agredidos, sendo que $14,7 \%$ das agredidas gritam enquanto apenas $1,1 \%$ dos agredidos admitiram fazer isso). Nas favelas, revidar tem o dobro, entre os homens $(70 \%)$ e as mulheres (50\%), das proporções encontradas na cidade, embora permaneça a tendência de que esta resposta seja mais comum entre os homens. A resposta agressiva e a menor tentativa de diálogo exibem outra vez a configuração social na favela, que apela para valores e práticas derivadas de formação subjetiva com disposição para resposta violentas em situações desafiadoras ou de conflito.

A procura da polícia após a agressão também difere entre vítimas do sexo masculino e feminino. No cômputo geral, $81,5 \%$ das pessoas agredidas não procuraram a polícia. As mulheres procuraram 
mais do que os homens (25\% para 10\% respectivamente). Porém, o dado mais revelador sobre a natureza diversa da agressão entre homens e mulheres é que foram as próprias características - muito mais pessoais - da agressão contra mulheres que se revelaram como o motivo para que as agredidas não procurassem a polícia.

As pessoas que não procuraram a polícia apresentaram como justificativa principal o medo de sofrer represálias dos agressores $(21,7 \%)$, o fato de achar que não valia a pena, ou de que seria difícil a polícia atender a reclamações de agressões, ou de que perderiam muito tempo $(20,3 \%)$, ou, ainda, de que não teriam informações que pudessem ajudar a polícia (10,8\%), além de justificativas como razões pessoais e razões práticas, somando $52,8 \%$ que não consideram a agressão uma questão para ser resolvida pela polícia. Ainda $12,1 \%$ das pessoas agredidas afirmaram ter resolvido o problema por meios próprios. Somados, são $64,9 \%$ os que percebem mais problemas pessoais e práticos do que de confiança na polícia.

Entre os homens agredidos, os motivos apresentados para não procurarem a polícia indicam que $25,4 \%$ deles não têm confiança na instituição. Razões práticas para não fazer queixa foram dadas por $34,9 \%$ dos homens agredidos, proporção pouco menor do que a encontrada entre as mulheres. Medo de represália foi a justificativa dada por $21,1 \%$ deles, o que não está necessariamente vinculado a agressores familiares ou íntimos, visto que meros conhecidos ou pessoas armadas da vizinhança também costumam ameaçar o revide caso haja denúncia à polícia (Zaluar, 2004). A razão vinculada a questões familiares atinge apenas $8,2 \%$ do total de motivos apresentados pelos homens agredidos.

Quanto às mulheres, os dados vão demonstrar que a proximidade da vitima com o agressor é importante razão para não apresentar queixa na polícia. A falta de confiança na instituição é proporcionalmente três vezes menos relevante entre as mulheres do que entre os homens: apenas $8,2 \%$ delas justificaram a falta de denúncia pela desconfiança em contraponto ao índice de $25,4 \%$ entre os homens. Homens e mulheres concordam quanto à certeza que não iria adiantar prestar queixa, pois é difícil a polícia atender a casos de agressão: as proporções de ambos estão em 15\%. E se somarmos todas as justificativas de ordem prática para não dar queixa apresentadas pelas mulheres, estas somam 35,5\%.

Já o medo de represália atinge apenas um pouco mais as mulheres do que os homens: $22,3 \%$ das mulheres não vão à polícia por este motivo em contraponto a $21 \%$ dos homens. Esta é a principal razão para não prestar queixa na polícia, o que aponta para a continuidade da situação de conflito no caso de agressões físicas por envolverem pessoas conhecidas. Como sabemos que quase $80 \%$ dos agressores das mulheres são pessoas próximas, pode-se concluir que este medo decorre da continuidade da relação com o agressor, questão muito discutida na literatura a respeito da violência doméstica e familiar (Vianna e Lacerda, 2004, pp. $20-$ 23; Correa, 2002). Destas mulheres que não apresentam queixa por medo de represália, de fato $83 \%$ foram agredidas por parentes e afins. Se acrescentarmos os vizinhos agressores, essa proporção vai para 94,3\% de mulheres agredidas por pessoas próximas. Os motivos apresentados para evitar a ocorrência policial que apontam diretamente para as relações familiares é também o dobro da apresentada pelos homens: $16 \%$ delas para $8,2 \%$ deles.

Mas há também uma enorme diferença entre as mulheres que afirmaram ter resolvido o problema por meios próprios $(12,1 \%)$ e os homens que optaram por afirmar que o uso de meios próprios foi suficiente $(1,5 \%)$. As mulheres agredidas que apresentaram essa justificativa sofreram a violência principalmente de pessoas próximas: afins, amigos e vizinhos (63\%). Isso indica que, embora as mulheres sejam mais agredidas e que o sejam principalmente por pessoas próximas, a continuidade da relação faz com que a agressão seja discutida, perdoada ou esquecida para não interrompê-la. ${ }^{4}$ Mas é possível que o revide da agressão entre amigos e vizinhos tenha resultado em agressões mútuas, ou seja, uma briga.

Não há dúvida, pois, de que os padrões de agressão entre homens e mulheres são diferentes no que tange aos aspectos privado e público, o que influenciará o fato de não registrar a ocorrência policial. Por fim, tudo indica que as mulheres esquecem, negociam ou perdoam as agressões cometidas contra elas, quando se considera que os 
meios próprios para resolver o problema foram considerados suficientes por $12,1 \%$ delas, enquanto apenas $1,5 \%$ dos homens afirmaram o mesmo. Destas mulheres que resolvem o conflito por meios próprios, 63\% foram agredidas por parentes, afins ou amigos.

\section{Conclusões}

Diante de tantos dados que apontam para o padrão familiar ou íntimo da agressão contra a mulher, é possível afirmar que a agressão contra ela tem a ver com a dominação e as ameaças ao poder viril, objeto de acalorada polêmica no Brasil e no mundo, até mesmo entre feministas. Algumas destas no Brasil continuam a afirmar que a violência doméstica ou familiar, com o seu poder viril incontestável, é a continuação do patriarcalismo brasileiro, nascido e criado na Casa Grande das plantations de açúcar no período colonial. Como esta formação social pode caracterizar a sociedade brasileira, mas não outras onde também ocorrem crescentes formas de violência doméstica, o recurso a outros conceitos mundialmente usados, o de hipermasculinidade e de etos guerreiro, podem ser mais frutíferos.

Além disso, segundo Gilberto Freyre (1977), o criador do conceito da família patriarcal brasileira, esta formação estaria em desagregação desde o século XVII. Portanto, séculos nos separam da constelação de relações e formações subjetivas da família patriarcal, tal como se constituiu no século XVI. Em Sobrados e mucambos, Freyre reconstitui os processos culturais que vão gerar a formação social brasileira, abordando os mecanismos de distanciamento e aproximação, ruptura e união na classe, na raça, na cultura, segmentadas por outros vetores sociais: o gênero, a idade, a família. A classe, a raça e a cultura, que se diferenciam no distanciamento e no confronto, vão perdendo seus contornos nítidos e suas separações dicotômicas e ganhando ambivalências e tensões que lhes trazem dinâmica e criatividade. As trocas duais, tão intensas entre a casa-grande e a senzala (termos mencionados sempre no singular), raiz da família patriarcal brasileira, nos sobrados e mucambos (referidos sempre no plural) vão abrindo brechas que abalam o sistema dual, gerando diversificações múltiplas e conflitos antes inexistentes. A família patriarcal brasileira torna-se repleta de fragilidades, conflitos e ambigüidades, perdendo o homem sua posição de poder (Freyre, 1977).

Aparte a dificuldade histórica que induz uma análise mais cuidadosa e precisa do que se entende por família patriarcal brasileira, este modelo de família não explica nem as agressões cometidas por homens contra homens nem as variações assinaladas nas diferentes categorias de mulheres por estado civil, idade, renda e escolaridade, sem falar nas diferenças assinaladas entre as favelas e a cidade.

A interpretação aqui adotada é a de que os três aspectos mencionados para decifrar as diferenças nos percentuais de pessoas agredidas segundo o estado civil devem ser levados em consideração. A rede de solidariedade que envolve os cônjuges, o ritual judicial que interpõe a autoridade de um terceiro à relação, assim como o estilo de vida mais conservador ou de maior compromisso mútuo e de laços mais permanentes dos que se casam judicialmente, tudo isso contribui para diminuir o risco de agressão, cada um com dinâmica diferente, porém interconectada.

Essa linha de argumentação também permite fazer ajustes a outras teorias cada vez mais usadas na explicação das taxas diferentes de criminalidade encontradas em espaços diversos. Dizem respeito ao capital social, à cultura cívica ou à eficácia coletiva atribuídos a vizinhanças, bairros, cidades ou comunidades. As áreas urbanas com mais associações vicinais apresentariam, dessa perspectiva, taxas de criminalidade mais baixas, escolas mais eficientes, mais adultos responsáveis controlando crianças e jovens (Sampson et al., 1997). O conceito de capital social, muito usado como explicação para o sucesso ou o fracasso de políticas em diferentes áreas, daria conta da capacidade de estabelecer laços de confiança interpessoais e redes de cooperação com o objetivo de produzir bens coletivos (D'Araújo, 2003). Todos esses conceitos envolvem formas de identidade, comunidade e vizinhança, redes de sociabilidade, reciprocidade e solidariedade, relações de cooperação e respeito. Como estão vinculados a redes sociais mais do que a características físicas ou simbólicas de áreas urbanas, a mesma abordagem poderia ser referida a grupos 
domésticos e redes sociais mais amplas, que se estendem para além das vizinhanças.

Assim sendo, ao contrário do que sugere a teoria da família patriarcal, grupos domésticos ou famílias extensas podem apresentar redes de relações entre seus participantes com maior ou menor cooperação, controle e cuidado, criando formas de proteção informal a agressões, muito antes que qualquer polícia venha a fazê-lo com a sua presença ou competência de punir os agressores. Algumas famílias têm, de fato, uma capacidade maior de proteger os mais vulneráveis entre seus membros, incluídos aí mulheres em idade reprodutiva e homens jovens. Justamente famílias mais conservadoras, que mantêm os valores tradicionais de solidariedade, porém exclusiva ao grupo de parentesco.

A migração interurbana e interestadual enfraqueceria essa capacidade guardiã das organizações familiares e, no momento, ainda não teria desenvolvido novas formas de solidariedade por manifestar apenas a liberdade individual que não estimula laços adquiridos com a convivência entre estranhos no contexto urbano (Zubero, 2008). A fácil desintegração dos laços matrimoniais em uniões consensuais, ou seja, as relações intermitentes e pouco duradouras também seriam muito mais a expressão de individualismo atomizador do que o exercício da liberdade em um contexto social integrador, o que leva autores a falar sobre a família no contexto da globalização como uma categoria zumbi (Beck e Gernsheim, 2001), cujo grupo mais vulnerável consiste em mulheres que criam sozinhas seus filhos (Fleury, Subirats e Blanco, 2008).

Mas não é correto supor que todas as famílias chefiadas por mulheres estejam nessa situação, nem que somente tais famílias permanecem isoladas de redes de solidariedade. É preciso, pois, atentar para o fato de que tais redes se espraiam pela vizinhança, pela cidade, podendo proporcionar, portanto, proteção. As famílias, quaisquer que sejam seus padrões, nem sempre estão isoladas de redes sociais, e se vinculam a elas de formas diferenciadas, ainda por serem estudadas, ou são estimuladas por políticas públicas a criarem esse tipo de vínculo.

Do mesmo modo, é necessário prestar atenção ao que acontece na vizinhança, no bairro ou na cidade não apenas desde a perspectiva da liberdade individual ou a teoria de um sujeito central, mas incorporando a problemática da intersubjetividade, que faz da socialização em laços sociais plurais a marca da contemporaneidade pluralista e democrática. Isso possibilitaria as pontes que reúnem grupos dispersos ou diferentes no contexto urbano definido justamente como o encontro do diverso. Não apenas a criação de laços em grupos exclusivos - bonding -, como acontece tradicionalmente, mas também os percursos que permitiriam o entendimento e a ligação entre os diferentes - bridging (Putnam, 1996).

Por outro lado, há importantes transformações sociais globais que atingem simultaneamente várias formações sociais e subjetivas no mundo. Novas identidades e práticas masculinas vinculadas à dominação masculina e ao poder definido como característica viril foram surgindo e se cristalizando em processos sociais já bem estudados. Nesse caso, não se trata da continuidade da família patriarcal, mas sim de uma sociedade em que toda autoridade tradicional está em crise, inclusive a dos pais, na qual o poder fragilizado vem a ser exercido com a exigência de uma submissão sem falhas e uma obediência incondicional dos(as) dominados(as). Sinal de fraqueza, e não de força.

Norbert Elias (1997), em suas obras sobre o processo civilizatório na Europa ocidental, especialmente na França e na Inglaterra, desenvolve o conceito de etos guerreiro para caracterizar aquela formação subjetiva em que não se interiorizaram os controles da emoção que tornam o sujeito capaz de evitar uma resposta belicosa a desafios e disputas. O habitus civilizado, segundo o autor, seria o resultado de longo processo histórico, no qual o monopólio legítimo da violência pelo Estado foi acompanhado por disposições psíquicas e práticas do jogo parlamentar, do fair play nos jogos esportivos e dos hábitos corteses que resultaram na civilidade da coexistência entre os diferentes, sem que conflitos e competições terminassem na destruição física do adversário. Mas esse processo estaria sempre vulnerável a retrocessos, como os que foram verificados na violência das torcidas organizadas, conhecida na Inglaterra como o fenômeno do hooliganism (Elias e Dunning, 1993; Monteiro, 2003). 
Por isso mesmo, no reverso do processo civilizatório, encontra-se a hipermasculinidade, fenômeno bem estudado em países onde nunca existiu a família patriarcal aos moldes brasileiros, especialmente nos Estados Unidos da América. Ali, esse fenômeno foi definido como a "constelação de personalidade" com um conjunto de traços relativos à agressão sexual (Holand e Scourfield, 2000): atitudes sexuais cruéis para com as mulheres, uso de bebidas alcoólicas, agressividade, dominação e perigo valorizados como características viris. Em contrapartida, a empatia, o cuidado e a compreensão são encarados como sentimentos e atitudes femininas, não como "coisas de homens de verdade", ou seja, os homens que agridem mulheres ou se agridem entre si por qualquer desafio à virilidade. Por inibir a expressão de características femininas ao considerá-las fracas e inapropriadas para "homens de verdade" ou "sujeitos-homens", a hipermasculinidade traria como conseqüência a inabilidade em expressar empatia com a vítima potencial de sua agressividade (Norris et al., 1999), seja ela homem ou mulher. É isto que facilitaria a resposta agressiva em quaisquer conflitos que ameacem a posição de domínio do homem que apresenta tais disposições internas.

Este é o modelo de análise mais adequado, na medida em que explica tanto as agressões cometidas por homens contra mulheres, considerando a relativa vulnerabilidade de cada categoria de mulheres, como as agressões mútuas entre homens. $\mathrm{Ou}$ seja, elucida por que os homens em contextos sociais específicos são mais propícios a brigar entre si, conhecendo-se ou não, ao passo que algumas mulheres tendem a apanhar de homens próximos, e esclarece tanto a lógica da resposta ao desafio, na recusa a qualquer submissão, como a lógica da obediência pelo medo, na submissão ao domínio masculino. Nos dois padrões de agressão física - a pública e a privada -, trata-se da afirmação do etos da masculinidade dominadora que torna essa formação subjetiva menos propensa a adotar as práticas da civilidade e da igualdade entre pessoas e gêneros.

Dessa forma, apostar apenas em policiamento localizado nas vizinhanças mais violentas terá pouco efeito na diminuição do risco potencial para as categorias de pessoa assinaladas neste texto. Ao contrário, as políticas públicas de prevenção da violência, também chamadas de non-crime policies por Sampson (1995), tais como promover ou incentivar a construção de redes de solidariedade na vizinhança e na família, aumentando o nível de confiança mútua e promovendo a ação coletiva dos moradores e dos familiares, até mesmo para montar grupos de discussão ou de terapia de vítimas e de agressores, podem resultar, de fato, em maior eficácia no controle deste e de outros crimes.

\section{Notas}

1 O teste de qui quadrado, que estima a razão entre os resultados esperados e os observa- dos, apontou que a diferença de risco por sexo não é estatisticamente significante na cidade ( $\mathrm{p}=0,113702)$ e menos ainda na favela ( $p=0,862434)$. Agradeço ao prof. Mario F. G. Monteiro o cálculo dos testes aqui apresentados, bem como o cálculo de alguns gráficos.

2 O teste de qui quadrado revelou que a diferença no risco por grupo de idade é altamente significante na cidade $(\mathrm{p}=0,00000)$ e significante na favela $(\mathrm{p}=0,01429)$.

3 No teste de qui quadrado, a diferença de risco por renda familiar, de fato, revelou ser altamente significante na cidade $(p=0,0040)$, mas não na favela $(\mathrm{p}=0,13027)$, devido à maior homogeneidade socioeconômica ou concentração de pobres na favela.

4 Tema bastante apontado na literatura a respeito do assunto (ver Couto, 2005).

\section{BIBLIOGRAFIA}

BAUMAN, Zygmunt. (2003), Comunidade: a buscapor segurança no mundo atual. Rio de Janeiro, Jorge Zahar Editor.

BECK, Ulrich \& GERNSHEIM, Elisabeth B. (2001). Individualization, institucionalized individualism and its social and political consequences. Londres, Sage Publications.

BOURDIEU, Pierre. (1972), Esquisse d'une theorie de la pratique. Paris, Plon.

CECCHETTO, Fátima. (2004), Violência e estilos de masculinidade. Rio de Janeiro, Editora FGV. 
CORNWALL, A. \& LINDISFARNE, N. (1996), Dislocating masculinity. Londres, Routledge.

CORREA, Marisa. (2002), "Gênero e cidadania". Pagu, Campinas.

COUTO, Sonia (2005). Violência doméstica: uma nova intervenção terapêutica. Belo Horizonte, Autentica/FCH-Fumec.

D'ARAUJO, Maria Celina. (2003), Capital social. Rio de Janeiro, Jorge Zahar.

ELIAS, Norbert. (1997), Os alemães, a luta pelo poder e a evolucão do babitus nos séculos XIX e XX. Rio de Janeiro, Jorge Zahar.

ELIAS, Norbert \& DUNNING, Eric. (1993), Quest for excitement, sport and leisure in the civilizing process. Oxford, Oxford University Press.

FLEURY, Sonia; SUBIRATS, Joan \& BLANCO, Ismael (eds.). (2008), "Introducion", in , Respuestas locales a inseguridades globales. Barcelona, Funcació Cidob.

FREYRE, Gilberto. (1977) Sobrados e mucambos. Rio de Janeiro, Livraria José Olympio/MEC.

HOLLAND, Sally \& COURFIELD, Jonathan B. (2000), "Managing marginalised masculinities: men and probation". Journal of Gender Studies, 9 (2).

MACDOWELL, Linda. (2000), "The trouble with men? Young people, gender transformations and the crisis of masculinity". International Journal of Urban and Regional Research, 24 (1).

MONTEIRO, Rodrigo de Araújo. (2003), Torcer, lutar, ao inimigo massacrar: raça rubro negra. Rio de Janeiro, Editora da FGV.

NORRIS, Jeanette et al. (1999), "Alcohol and hypermasculinity as determinants of men's empathic responses to violent pornography". Journal of Interpersonal Violence, 14 (7): 683-700.

PUTNAM, Robert D. (1996), Comunidade e democracia: a experiência da Itália moderna. $1^{a}$ edição. Rio de Janeiro, Editora da FGV.

SAMPSON, Robert. J. (1995), "The community", in J. Q. Wilson \& J. Petersilia (eds.), Crime, San Francisco, ICS Press.

SAMPSON, Robert J. et al. (1997), "Neighborhoods and violent crime: a multilevel study of collective efficacy". Consultado no site http:// www.wjh.harvard.edu/soc/faculty/sampson/ articles/1997_Science.pdf.

SIMIÃO, Daniel Schroeter. (2006), "Representan- do corpo e violência, a invenção da 'violência doméstica' em Timor-Leste". Revista Brasileira de Ciências Sociais, 21 (61).

VIANNA, Adriana \& LACERDA, Paula. (2004), Direitos e políticas sexuais no Brasil: o panorama atual. Rio de Janeiro, CEPESC.

ZALUAR, Alba. (2004), Integração perversa: pobreza e tráfico de drogas. Rio de Janeiro, Editora FGV.

ZALUAR, Alba \& CONCEIÇÃO, Isabel S. (2007), "Favelas sob o controle das 'Milícias' no Rio de Janeiro: que paz?". São Paulo em Perspectiva, 21(2).

ZUBERO, Imanol. (2008), “Construcción y deconstrucción de extraños en el ámbito local: de las identidades predadoras a las identificaciones dialogantes", in Sonia Fleury, Joan Sibirats e Ismael Blanco (eds.), Respuestas locales a inseguridades globales, Barcelona, Fundació Cidob. 


\section{AGRESSÃO FÍSICA E GÊNERO NA CIDADE DO RIO DE JANEIRO}

\author{
Alba Zaluar \\ Palavras-chave: Vitimização; Gênero; \\ Favela; Cidade; Hipermasculinidade.
}

Este artigo tem como objetivo analisar a especificidade da agressão física como um dos crimes mais comumente registrados em pesquisas de vitimização, em comparação a furtos e roubos. A autora discute a aplicação da teoria da escolha racional nessas pesquisas, pois seria inadequada, no caso específico da agressão física, para entender a relação entre o contexto social e o risco de vitimização, marcadamente diferente para homens e mulheres e relacionado com poder e reconhecimento mais do que ganhos materiais. As diferenças constatadas no padrão feminino e masculino de vitimização pela agressão não poderia continuar a ser interpretadas apenas pela teoria da família patriarcal, mas deve-se atentar para as mudanças ocorridas nas cidades, nos padrões familiares e na construção da masculinidade no processo de globalização, tal como proposta na teoria da hipermasculinidade ou a do etos guerreiro. Isto pode sugerir mudanças nas políticas públicas voltadas para a prevenção da violência.

\section{PHYSICAL AGGRESSION AND GENDER IN RIO DE JANEIRO CITY}

Alba Zaluar

Keywords: Victimization; Gender; Favela; City; Hyper masculinity.

This article discusses a specific crime assault - usually registered in domicile victimization surveys, as compared to stealing and robberies. It debates whether rational choice theory is suitable to understand crimes as registered in theses surveys. As far as assault is concerned, this theory is unable to explain the association between social context and victimization risk, markedly different for women and men, as well as more linked to power and recognition than to material gains or assets. Furthermore, the differences between feminine and masculine patterns of victimization by assault could not be interpreted only by the commonly used theory of the patriarchal family, and should be illuminated by recent changes in urban life, family patterns and in the construction of masculine identities and practices, as suggested by the theories of hyper masculinity or warrior ethos. This may be useful for changing public policies aiming prevention of violence in interpersonal relationships.

\section{AGRESSION PHYSIQUE ET GENRE DANS LA VILLE DE RIO DE JANEIRO}

\section{Alba Zaluar}

Mots-clés: Victimization; Genre; Favela; Ville; Hypermasculinité.

L'objectif de cet article est d'analyser, par rapport aux larcins et aux vols, la spécificité de l'agression physique comme l'un des crimes les plus couramment rapportés dans les recherches de victimisation. L'auteur discute l'application, dans ces recherches, de la théorie du choix rationnel. Elle considère que, dans le cas spécifique de l'agression physique, cette théorie serait inapproprié pour comprendre le rapport entre le contexte social et le risque de victimisation, définitivement différent pour les hommes et pour les femmes, et lié au pouvoir et à la reconnaissance plutôt qu'aux gains matériels. Les différences identifiées dans les modèles masculin et féminin de victimisation par agression ne pouvaient pas continuer à être interprétées uniquement par la théorie de la famille patriarcale. Nous devons également considérer les changements qui ont eu lieu dans les villes, dans les modèles familiaux et dans la construction de la masculinité suite au processus de globalisation, tel que le proposent la théorie de l'hypermasculinité ou celle de l'ethos guerrier. Cela peut suggérer des changements dans les politiques publiques tournées vers la prévention de la violence. 